\title{
Development of Urban Electric Bus Drivetrain
}

\author{
Oleg Sivkov ${ }^{1)}$, Lubomir Musalek ${ }^{2)}$, Jaroslav Novak ${ }^{3)}$, Martin Novak ${ }^{4)}$ Jan Chysky ${ }^{5)}$, and Lukas Novak ${ }^{6}$ \\ 1) Czech Technical University in Prague, Faculty of Mechanical Engineering, Prague, Czech Republic, \\ e-mail: oleg.sivkov@fs.cvut.cz \\ ${ }^{2)}$ Czech Technical University in Prague, Faculty of Mechanical Engineering, Prague, Czech Republic, e-mail: \\ lubomir.musalek@fs.cvut.cz \\ ${ }^{3)}$ Czech Technical University in Prague, Faculty of Mechanical Engineering, Prague, Czech Republic, e-mail: \\ jaroslav.novak@fs.cvut.cz \\ ${ }^{4)}$ Czech Technical University in Prague, Faculty of Mechanical Engineering, Prague, Czech Republic, e-mail: \\ martin.novak@fs.cvut.cz \\ ${ }^{5)}$ Czech Technical University in Prague, Faculty of Mechanical Engineering, Prague, Czech Republic, e-mail: \\ jan.chysky@fs.cvut.cz. \\ ${ }^{6}$ Czech Technical University in Prague, Faculty of Mechanical Engineering, Prague, Czech Republic, e-mail: \\ lukas.novak@fs.cvut.cz.
}

\begin{abstract}
The development of the drivetrain for a new series of urban electric buses is presented in the paper. The traction and design properties of several drive variants are compared. The efficiency of the drive was tested using simulation calculations of the vehicle rides based on data from real bus lines in Prague. The results of the design work and simulation calculations are presented in the paper.
\end{abstract}

Keywords - Electric Bus; traction battery; simulation calculation; drive concept.

\section{INTRODUCTION}

The main goals of the project can be summarized as follows:

1. Proposal of a new concept for a drivetrain with increased efficiency.

2. Specify the main parameters of the drivetrain components.

3. Verification through simulation and optimization of the parameters for the drivetrain components (simulation of vehicle driving in real routes, evaluation of traction and energy parameters).

4. Specify battery cell parameters.

5. Verify experimentally the properties of considered battery cells and the measurement results in the use of simulation calculations.

6. Proposal of the electromechanical converter design.

7. Proposal regarding the construction and control of the converter part.

8. Proposal regarding the construction of battery equipment and battery management system.

9. Implement the drive unit and the converter equipment.

10. Perform laboratory tests of the drive unit and converter equipment.

11. Install the drive system, converter equipment, and battery on the vehicle.

12. Realize commissioning of the drive system.

13. Conduct extensive testing and evaluation of the system.
The Faculty of Mechanical Engineering of CTU in Prague is mainly involved in activities 1 to 5, 10 and 13 of the mentioned above points. At present, the activities in points 1, 2, 3 are currently being processed. An experimental background for testing battery cells according to point 5 has been implemented.

\section{ElECTROBUS POWER SUPPLY STRUCTURE}

The structure of the electric bus drivetrain is relatively simple and standard. The input DC circuit of the traction inverter is supplied from the rechargeable battery via a bidirectional DC / DC converter which supplies the threephase motor. There is a system of mechanical energy transfer to the axle.

The DC / DC converter is used to adjust the voltage levels of the battery and the input of the traction inverter. At the same time, it stabilizes the input voltage of the inverter and eliminates battery voltage fluctuations due to its discharge and voltage drop at the internal resistance.

The traction inverter has a standard connection; it is a three-phase bridge with six IGBTs and six flyback diodes. The traction inverter forms an output three-phase system using pulse width modulation (PWM).

The innovation compared to current SOR electric buses, which are equipped with traction induction motors, is the vision to use a permanent magnet synchronous motor (PMSM). Using a PMSM can be characterized in the following points:

- Smaller dimensions and weight compared to induction motor.

- $\quad$ Larger torque overload than an induction motor (up to $3 \times$ ).

- Instantaneous response for the transition to electrodynamics' brake due to permanent magnet excitation.

- The necessity of solution of motor disconnection in case of traction circuit faults (magnetic flux is permanent in motor).

A dominant feature of PMSM compared to induction motors is the reduction of dimensions and weight. Several differences are compared to the asynchronous motor, also 
in the solution of the torque control structure and the necessity of using the rotor angle sensor. This issue was previously addressed in [6].

A conceptual issue that has not yet been resolved is the concept of transferring mechanical energy from the electric motor shaft to the axle. An axle gearbox is used in each case. Further, the structure of mechanical transmission may be processed via two options:

1. Transmission from the motor shaft directly to the input axle transmissions.

2. Inserting a shiftable gearbox between the engine and axle transmission.

In the case of a shiftable gearbox, two gear reductions are considered. The first gear reduction with the transfer gear embedded 1.8 and the second gear reduction where the torque is transmitted from the engine directly to the input axle transmission i.e. with the first gear. The insertion of a shiftable gearbox complicates the design and deteriorates driving characteristics, especially the pulling and braking forces of the gear shift. On the other hand, using a shiftable gearbox provides background for smaller dimensions and weight of the motor to achieve a higher climbing rate and use of a lower voltage. Support for the decision on the final version is obtained by simulation calculations of the vehicle on specific routes.

\section{SPECIFICATION OF MAIN DRIVE PARAMETERS}

When designing the main drive and motor parameters, it is necessary to take into account the main requirements of the vehicle and other limiting requirements given by the design of both mechanical and electrical parts. For a quick calculation of basic parameters, especially for the electric motor, the calculation of parameters in the MS EXCEL was prepared at CTU Faculty of Mechanical Engineering. The calculation assume the use of a permanent magnet synchronous motor (PMSM). The following values are entered as input variables:

- Limit voltage $U_{\max }$, which is limited primarily by the voltage level of the power semiconductor components of the traction converter. The maximum voltage is limited to $1000 \mathrm{~V}$ for safety reasons and mainly for reasons of legislation, so that people trained for low voltage could work on that equipment.

- Total mechanical gear reduction ratio $\mathrm{i}_{\text {total }}$ is specified as the product of individual gearbox gear ratio.

- The total efficiency of the transmission $\eta_{\text {total }}$ is the product of both gearboxes efficiency.

- Wheel radius $\mathrm{r}_{\mathrm{w}}$.

- Maximum vehicle speed $v_{\max }$.

- The relative speed of the motor to field weakening related to the maximum motor speed $\mathrm{n}_{\text {Fluxweakening. }}$

- $\quad$ The relative voltage drop across $\mathrm{R}$ and $\mathrm{L}$ on motor impedance $\Delta U_{R L r e l}$ at a nominal speed of the motor.

- Weight of the vehicle $\mathrm{m}_{\mathrm{v}}$.

- Climbing rate of the vehicle in $\%$.

- Vehicle acceleration at maximum climb.

- The sum of the driving resistances of vehicle $F_{d r}$ in addition to the resistance from acceleration and resistance from the climb (air resistance, rolling resistance, resistances in vehicle components) - is given as constant, approximate, value and applies approximately to start and for low speed.

- Rotational mass coefficient $\xi$.

- Motor overload capacity $\mathrm{p}_{\mathrm{M}}$ as the ratio of maximum and nominal torque.

- Motor efficiency $\eta_{\mathrm{M}}$ - estimate.

- Motor power factor $\cos \varphi_{n}-$ estimate.

- Maximum and minimum cell voltage battery $\mathrm{U}_{\text {cellmax }}$ and $\mathrm{U}_{\text {cellmin. }}$.

- Maximum battery voltage $\mathrm{U}_{\text {batmax }}$.

- Inverter efficiency $\eta_{\text {Inv }}$ - estimate.

The calculation is based on the definition of the motor nominal values (voltage, current, torque) with which the motor can be operated indefinitely and on the overload limit values where it can operate for a limited time. If the motor is running in overload, the operation time is dependent on the amount of instantaneous overload. Due to the vector control torque motor structure, the equality of torque and current overload is assumed in the calculation. This equality applies exactly when flux weakening is not used. In flux weakening this equality is approximate. With the increasing speed at constant current overload, the torque overload decreases.

The calculation procedure is discussed in literature [1], [7]. Based on calculations 18 options of electric motors and gearboxes parameters were determined, and from these ten options, two priority options were selected. One with shiftable gearbox, the other with fixed torque transmission from motor to the axle gearbox input. The options can be characterized by the following main parameters:

\section{Fixed gear variant:}

Nominal motor power

$161 \mathrm{~kW}$

Vehicle climb rate

$20 \%$

Vehicle weight

$19.4 \mathrm{t}$

Voltage limit

$750 \mathrm{~V}$

Maximum vehicle speed

$80 \mathrm{~km} / \mathrm{h}$

Total gear ratio (on axle)

7.36

Acceleration at maximum climb

$0.1 \mathrm{~m} / \mathrm{s}^{2}$

Nominal torque of motor

$917 \mathrm{Nm}$

Nominal speed of motor

Maximum speed of motor

$1683 \mathrm{rpm}$

$3367 \mathrm{rpm}$

Nominal voltage of motor

$392 \mathrm{~V}$

Nominal current of motor

$251 \mathrm{~A}$

Torque and current overload

\section{Shiftable gearbox variant:}

Nominal motor power

$135 \mathrm{~kW}$

Vehicle climb rate

$22 \%$

Vehicle weight

$19.4 \mathrm{t}$

Voltage limit

$750 \mathrm{~V}$

Maximum vehicle speed

$90 \mathrm{~km} / \mathrm{h}$

Total gear ratio (axle+shiftable gearbox) 13.25

Acceleration at maximum climb $\quad 0.1 \mathrm{~m} / \mathrm{s}^{2}$

Nominal torque of motor

$620 \mathrm{Nm}$

Nominal speed of motor 


$\begin{array}{ll}\text { Maximum speed of motor } & 3789 \mathrm{rpm} \\ \text { Nominal voltage of motor } & 324 \mathrm{~V} \\ \text { Nominal current of motor } & 281 \mathrm{~A} \\ \text { Torque and current overload } & 3 \\ \text { Preferred shifting speed } & 50 \mathrm{~km} / \mathrm{h}\end{array}$

On comparison of the two variants, the shiftable gearbox has a smaller nominal power and smaller nominal current of the motor (323 A compared to $434 \mathrm{~A}$ ) which makes the construction of the electric equipment simpler and quicker. On the other hand, the mechanical construction is more complicated. Also, the drops in the pulling and braking force during shifting are problematic. This gear shifting takes about $0.5 \mathrm{~s}$.

\section{Circuit SOlution AND CONTROLled PUlSE RECTIFIER FUNCTION}

A simulation model for the calculation of bus behavior on defined routes was prepared. It was implemented for a detailed evaluation of the traction and energy properties of the drive unit. The input parameters of the model are:

- Route parameters (stops, speeds, slopes).

- Vehicle and drive unit parameters (weight, motor parameters, gear ratios, driving resistances).

The whole calculation is based mainly on the numerical solution of the vehicle motion equation.

The efficiency map is the basis for motor losses calculation. It is determined from the motor nameplate according to [1]. For illustrative purposes, Fig. 1 shows an efficiency map for a variable speed gear motor.

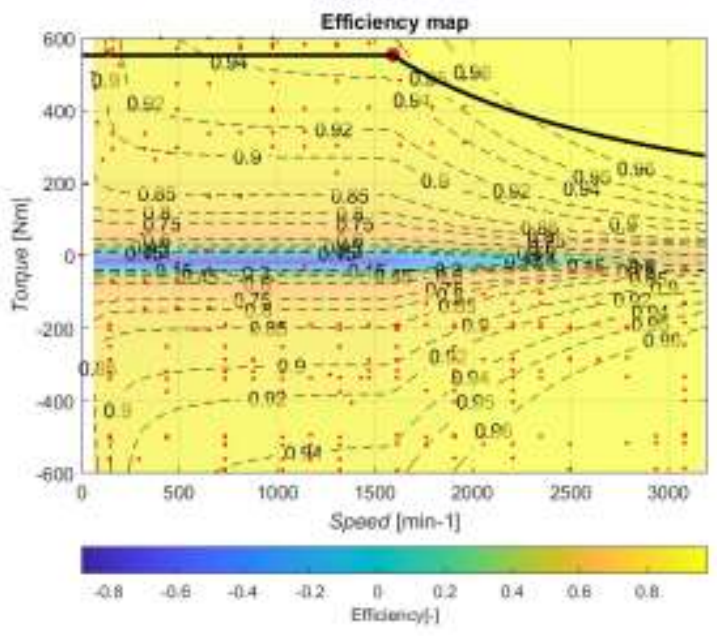

Fig. 1. Efficiency map of the motor with shiftable gearbox.

A rather complicated problem was the determination of the detailed route parameters, especially on the slope. The initial data was obtained via GPS. The route elevation was calculated from the height profile and the slope of route further from that. The route slope was determined from the height profile by parts of linear interpolation dividing into 20 linear sections. For further calculations, the route slope in a given linear section is considered to be constant. These simplifications are made in order to eliminate noise in the measured altitude data. Fig. 2 shows an example of the measured and linearized slope.

Tab. 1 illustrates examples of energy consumption calculations for two routes.

TABLE I.

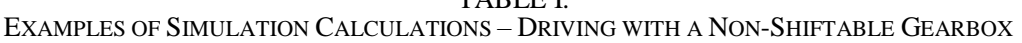

\begin{tabular}{|c|c|c|c|c|c|}
\hline Route & $\begin{array}{c}\text { Length } \\
(\mathbf{k m})\end{array}$ & $\begin{array}{c}\text { Consumption } \\
\mathbf{( k W h )} \\
\text { Without the slope }\end{array}$ & $\begin{array}{c}\text { Consumption } \\
\mathbf{( k W h / 1 0 0 k m )} \\
\text { Without the slope }\end{array}$ & $\begin{array}{c}\text { Consumption } \\
\text { (kWh) } \\
\text { With the slope }\end{array}$ & $\begin{array}{c}\text { Consumption } \\
\text { (kWh/100km) } \\
\text { With the slope }\end{array}$ \\
\hline Cycle SORT 2 & 0,937 & 0,78 & 83,3 & - & - \\
\hline $\begin{array}{c}\text { Na Knížecí -> } \\
\text { Jinonice, line } \\
137\end{array}$ & 4,73 & 2,7 & 57 & 5,8 & 122,6 \\
\hline $\begin{array}{c}\text { Na Knížecí -> } \\
\text { Jinonice, line } \\
137, \text { trip 2 }\end{array}$ & 4,73 & 2,2 & 46,5 & 5,9 & 124,7 \\
\hline $\begin{array}{c}\text { Na Knížecí -> } \\
\text { Jinonice, line } \\
137, \text { trip 3 }\end{array}$ & 4,73 & 2,7 & 57 & 5,8 & 122,6 \\
\hline $\begin{array}{c}\text { Na Knížecí -> } \\
\text { Jinonice, line } \\
137, \text { trip 4 }\end{array}$ & 4,73 & 2,2 & 46,5 & 5,9 & 124,7 \\
\hline $\begin{array}{c}\text { Smíchovské } \\
\text { nádraží -> } \\
\text { Sídliště Zbraslav }\end{array}$ & 13,2 & 9,2 & 69,7 & Slope is not & Slope is not \\
available & available \\
\hline
\end{tabular}




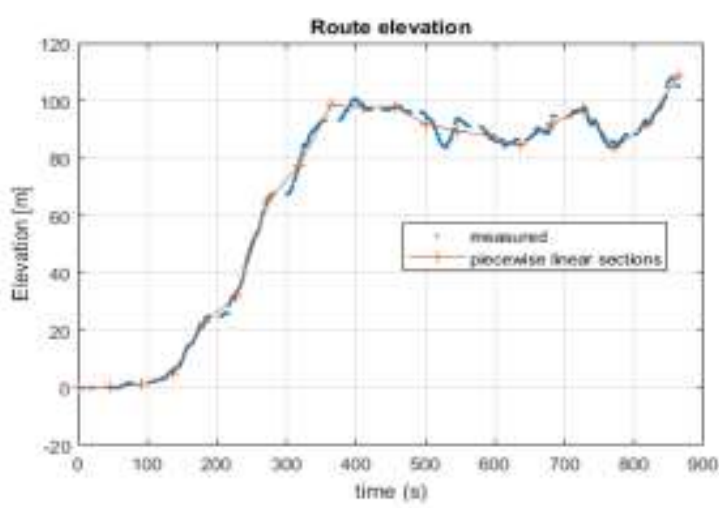

Fig. 2. Route profile - measured and linear interpolation, route "Na Knížecí" ==> "Jinonice”, bus line 137
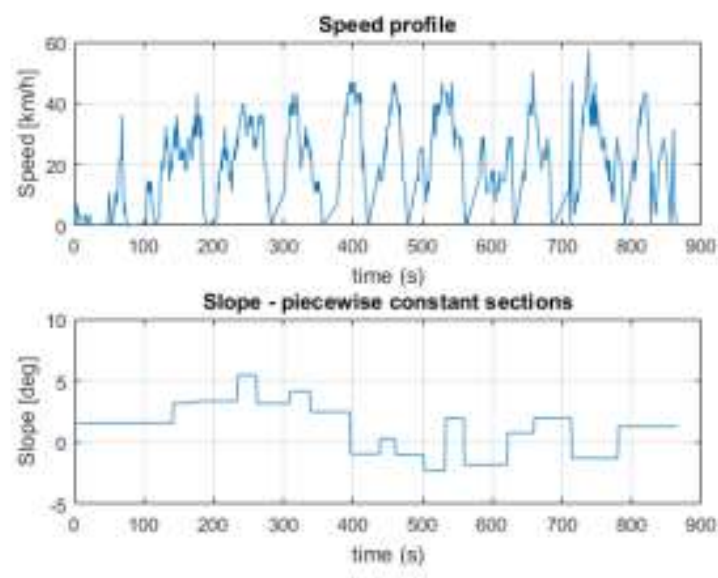

Fig. 3. Speed profile -measured and linear sections, route "Na Knížecí" ==> "Jinonice", bus line 137.

\section{High CAPACITY CELL TESTING FOR TRACTION BATTERY}

Battery cell parameters potentially usable for traction battery of the electric bus have been tested. Three types of cells are considered - cylindrical cells NMC with capacity $2 \mathrm{Ah}$, cylindrical cells NMC with capacity $3.2 \mathrm{Ah}$ and flat cells NMC with capacity $150 \mathrm{Ah}$. The testing system for $150 \mathrm{Ah}$ cells which is technically more complicated will be presented here.

This section will demonstrate an innovative way of solving problems of high current source and load with constant current demand regulation. The task was to measure the charging / discharging characteristics of the $150 \mathrm{Ah}$ battery Lion cell with a nominal voltage of $3.7 \mathrm{~V}$. The requirement was to charge and discharge the battery with a constant current $1 \mathrm{~A}$. The initial idea was to use a modified welding inverter. However, we had to leave this solution according to the problematic availability of the source for $150 \mathrm{Ah}$ of continuous load. Moreover, current control for such a low voltage was uncertain with the welding source. Another possible solution was to use a $3 \times 400 / 6 \mathrm{~V}, 600 \mathrm{VA}$ transformer with a rectifier. To obtain the output DC voltage, a six-pulse two-way 3-phase block rectifier with diodes ČKD Polovodiče D200/800 was used. For current control, a frequency converter Danfoss VLT FC 302 in scalar mode was used. A feedback signal from DC / DC current converter 5000:1 LEM LT500-T is connected to the input of current converter for feedback.

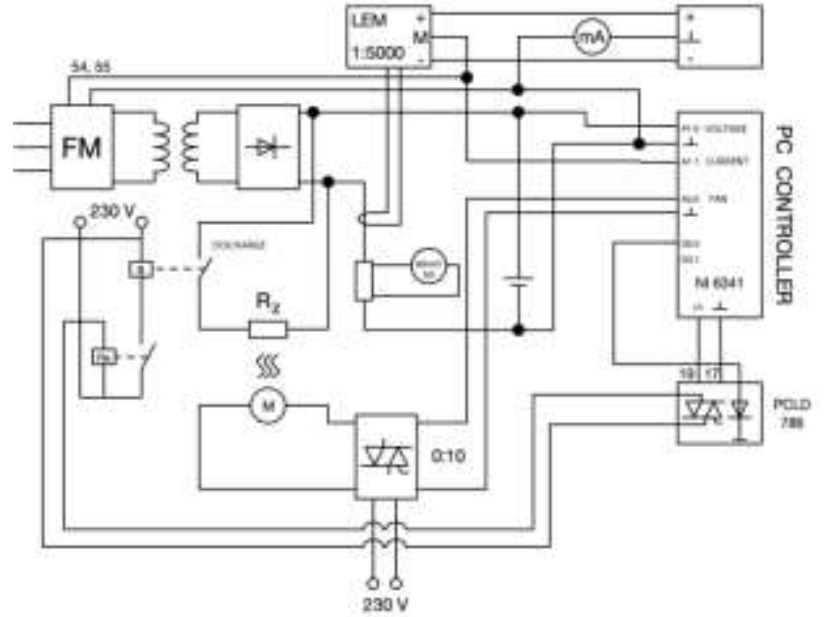

Fig. 4. Overall scheme for battery cell measurement $150 \mathrm{Ah}$.

For constant current discharge, a steel wire resistor of $2.4 \mathrm{~mm}$ diameter is used. The resistor value was selected to have the desired current passing through it when heated to approximately $400{ }^{\circ} \mathrm{C}$ with voltage of $4.2 \mathrm{~V}$. The resistor was cooled with an axial fan. When the battery voltage is reduced, the value of current and losses on the resistor is also reduced. Thus the resistance decreases and the current increases. For precise adjusting of the discharge current, the controller regulates the fan speed and thus the load resistor cooling and its resistance.

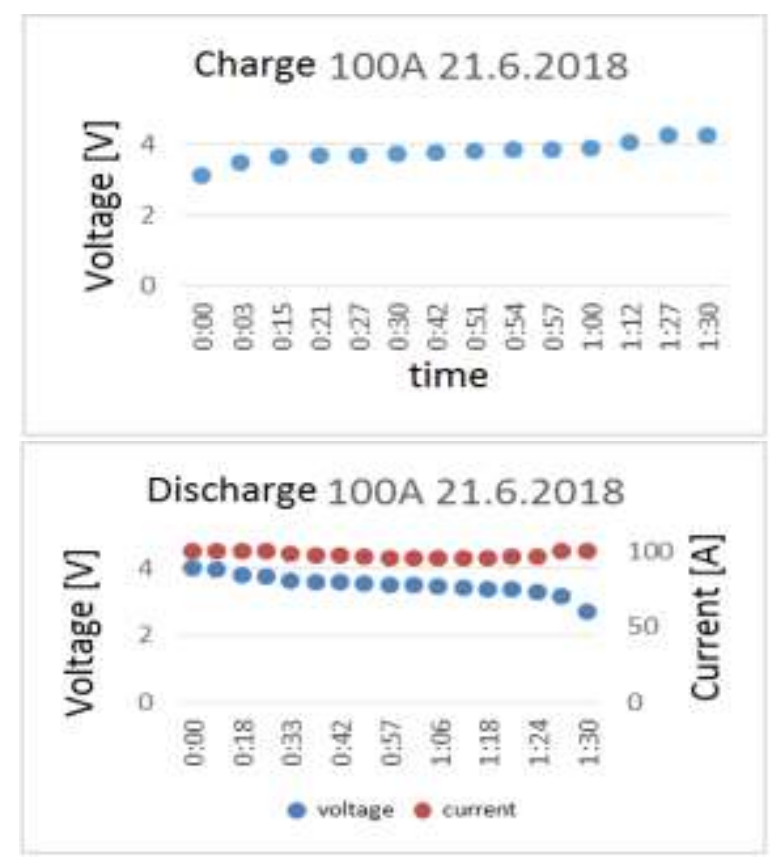

Fig. 5. Recorded charging and discharging process of the cell.

The possibility of non-conventional use of frequency converter as a control unit for a current source for battery charging and at the same time the possibility of regulating the discharge current by changing the temperature of the load resistor has been experimentally demonstrated.

\section{CONCLUSION}

The considered variants are a drivetrain with the shiftable gearbox but with shifting minimization or with no shifting and driving with a permanently engaged gear 1 (urban traffic) or 2 (intercity traffic in the flat section of 
track). At the same time, the specification of the rechargeable battery is prepared on the basis of energy simulation calculations.

\section{ACKNOWLEDGMENT}

This paper was supported by the project from the Czech Ministry of Industry and Trade, TRIO FV 30213 Research and development of traction system of an electric bus with higher efficiency.

Within the MPO TRIO program, a project focused on the development of a new drive system for the SOR electric bus was supported. The project investigators are the companies: SOR, Rail electronics (supplier of inverter equipment and control systems) and CTU in Prague, Faculty of Mechanical Engineering, Department of Instrumentation and Control Engineering.

\section{REFERENCES}

[1] J. Novák, M. Novák, Z. Novák, and J. Chyský, “Calculation and Experimental Investigation of Efficiency Map of Electric Motor" (in Czech: "Výpočet a experimentální vyšetřování účinnostní mapy elektromotoru"), in Proceedings of $X X X V$. Electric Drive Conference 2017, University of West Bohemia in Pilsen, 2017, ISBN 978-80-02-02724-9.

[2] J. Novák, O. Sadílek, and P. Sýkora, "Lithium Traction Accumulators for Electromobility" (in Czech: "Lithiové trakční akumulátory pro elektromobilitu"), Part 2, ELEKTRO 2016, Vol. 26, No. 11 and 12, published by FCC Public, Prague 2016, ISSN 0322-9025.

[3] SOR company materials

[4] Materials of the company Railelectronics

[5] VUES company materials

[6] J. Novák, Torque Control Structure for Traction Synchronous Motor with Permanent Magnets (in Czech: Regulační struktura momentu pro trakční synchronní motor s permanentními magnety), Technical Report for Railelectronics, CTU in Prague, Faculty of Mechanical Engineering, Prague, 2013.

[7] J. Novák and M. Novák, Selected Problems of Electrical Bus Electric Drive Design (in Czech: Vybrané problémy návrhu elektrického pohonu elektrobusu), Technical Report, CTU in Prague, Faculty of Mechanical Engineering, 2018.

[8] Danfoss company materials

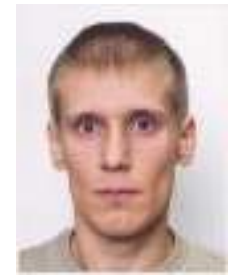

Oleg Sivkov got the MSc. degree in Electric engineering in 2002 from the Faculty of Electrical Engineering at South Ural State University in Chelyabinsk. In 2011 he has received a $\mathrm{PhD}$ degree from the Department of Electric Drives and Traction, Faculty of Electrical Engineering at Czech Technical University in Prague. He works as an assistant professor since 2013 at the Department of Instrumentation and Control Engineering, Faculty of Mechanical Engineering at Czech Technical University in Prague. He currently works with research in the field of controlling the permanent magnet synchronous motor. E-mail:oleg.sivkov@fs.cvut.cz

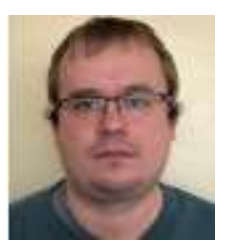

Lubomír Musálek graduated the specialization of Electric Power Engineering at Electric Engineering Faculty of CTU in Prague in 2011. He works at Faculty of Electric Engineering at Czech Technical University in Prague as an assistant professor. $\mathrm{He}$ is specialized in electrical power engineering. E-mail: lubomir.musalek@fs.cvut.cz

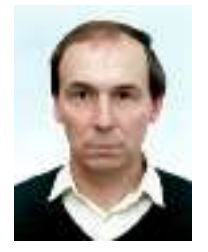

Jaroslav Novák received the MSc. degree in Power Electronics in 1989 from the Faculty of Electrical Engineering at the Czech Technical University in Prague, Czech Republic. In the year 1992 he has received a CSc. degree (Ph.D.) from the Department of Electrical Drives and Traction on the same faculty. He was working since 1992 as an assistant professor, since 2003 as an associated professor on the Department of Instrumentation and Control Engineering on the Faculty of Mechanical Engineering, CTU in Prague. Since 2011 he works as a professor at Transportation Faculty of Jan Perner of Pardubice University and continues cooperating with Mechanical Engineering Faculty of CTU in Prague. His main field of interest is electric drives, power electronics, electric traction, and microprocessor control.

E-mail: jaroslav.novak@fs.cvut.cz

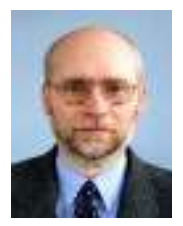

Jan Chyský is an associate professor graduated from the specialization Technical Cybernetics at Czech Technical University in Prague. After graduation, from 1979 he works at Faculty of Mechanical Engineering, gradually at the Departments of Automation and Electrical Engineering. In 1992 he was appointed an associate professor in the Electrical Engineering Division at Mechanical Engineering Faculty. From 2009 to 2019 he was the head of the Department of Instrumentation and Control Engineering. His professional activities are focused on the application of embedded systems for modeling, diagnostics and management of production facilities with a focus on reducing energy intensity and improving environmental parameters.

E-mail:jan.chysky@fs.cvut.cz

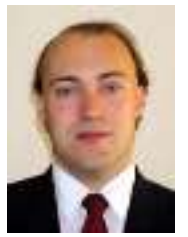

Martin Novák received the MSc. degree in Instrumentation and Control Engineering in 2003 from the Faculty of Mechanical Engineering at the Czech Technical University in Prague, Czech Republic. He continued with a PhD. degree (2008) at the same university. In 2013 he was appointed an associate professor. His main areas of interest are microcontrollers, signal processing, measuring methods and instruments, power electronics and control systems of permanent magnet synchronous machines.

E-mail: martin.novak@fs.cvut.cz

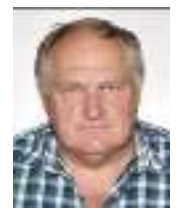

Lukáš Novák graduated the specialization of Electric Machines and Drives at Electric Engineering Faculty of CTU in Prague in 1984. He defended his doctoral thesis on Non-Disassembly Diagnostics of Combustion Engines in 2004. He works at Faculty of Electric Engineering at Czech Technical University in Prague as an associate professor. He is specialized in the automation of production machines and their drives.

E-mail: lukas.novak@fs.cvut.cz 